УДК 619.616.1/4.591.12.612.23

(C) 2012

Замазій А. А., доктор ветеринарних наук

Полтавська державна аграрна академія

Камбур М. Д., доктор ветеринарних наук

Сумський національний аграрний університет

\title{
ВИЗНАЧЕННЯ ФУНКЦІОНАЛЬНОГО СТАНУ ОРГАНІЗМУ НОВОНАРОДЖЕНИХ ТЕЛЯТ
}

\section{Рецензент - доктор ветеринарних наук В. О. Евстаф'ева}

Результати досліджень, наведені у статті, свідчать, шьо телята народжуються з різним рівнем функиіонального стану організму. Пренатальне недорозвинення тварин формується за умов порушення перебігу фізіологічних прочесів на трунті недостатнього забезпечення організму оксигеном. Наявність постійного контакту легенів із навколоплідною рідиною дає підстави апріорно вважати, щзо за якісним складом амніотичної рідини можна судити про стан плода, «зрілість сурфактантної системи легень» і прочессами, що в ній відбуваються, на що вказують окремі досліджені нами параметри. У зв'язку з ичим ми пропонуємо

20-бальну систему діагностичних тестів для оцінки «зрілості» сурфактантної системи легень, а, відповідно, й функиіонального стану організму новонароджених телят та ступеня впливу гіпоксї̈ на плід.

Ключові слова: сурфоктант, гіпоксія, плід, новонароджені, легені, навколоплідна рідина.

Постановка проблеми. Пренатальне недорозвинення новонароджених тварин зазвичай кваліфікують як гіпотрофію, беручи до уваги як головну ознаку лише масу тіла. Проте маса тіла не може бути основним показником пренатального розвитку тварин.

Пренатальне недорозвинення тварин, із нашого погляду, формується за умов порушення перебігу фізіологічних процесів на грунті недостатнього забезпечення організму оксигеном, що негативно позначається на забезпеченні організму енергією та процесах терморегуляції.

Відомо, що забезпечення організму плода оксигеном відбувається крізь матково-плацентарний комплекс. Порушення даного фізіологгічного процесу впливає на формування систем, які забезпечують адаптацію новонароджених тварин до нових умов існування, коли даний організм «вмирає» для однієї системи існування й «народжується» для іншої.

При цьому першочергового значення набуває функціональна активність системи, яка «приймає естафету» забезпечення організму оксигеном замість матково-плацентарного комплексу, тобто, сурфактантна система легень.

Враховуючи такий взаємозв'язок фізіологічних процесів забезпечення організму плода та новонароджених тварин оксисеном, набуває актуальності розробка системи діагностичних тестів, які дають змогу судити про пренатальний розвиток плода й «готовність» новонароджених тварин до існування у нових умовах. Система таких тестів базується на наявності постійного зв'язку між легенями плода й навколоплідною рідиною. Отже, за складом навколоплідної рідини можна судити про зрілість сурфактантної системи легень, функціональний стан організму плода, а, відповідно, й новонароджених телят.

Дослідження були складовою частиною тематичного плану кафедри біотехнології Полтавської державної аграрної академії, кафедри анатомії, нормальної та патологічної фізіології Сумського національного аграрного університету «Розробка мультипараметричної системи виробництва молока на основі секретоутворюючої функції молочної залози, пре- та постнатального розвитку тваринного організму і методів їх корекції», номер державної реєстрації 0108U010281 (Розділ 2. «Фізіологобіохімічні параметри пре- та постнатального розвитку тварин та їх корекція» (2006-2010рр.), а також теми «Розробити систему оцінки функціонального стану молочної залози та методи профілактики іiі порушень у корів у різні періоди лактації», номер державної реєстрації 0106U009414 (2005-2006рр.).

Аналіз основних досліджень і публікацій, у яких започатковано розв'язання проблеми. Для своєчасного першого вдиху та встановлення дихання потрібна достатня зрілість функціональної системи дихання, тобто легенів і механізмів, які регулюють їх функцію.

У 1929 р. уперше в легенях були відкриті поверхнево-активні речовини (ПАР) - сурфактант. Термін «сурфактант», як антиателектичний фактор, вперше введено в клінічну практику 
Clements у 1956 році. Він із часом розглядався як стабільна комплексна сполука ліпопротеїнової природи $з$ основним поверхнево-активним компонентом - дипальмітилфосфатидилхоліном. Функціональна система дихання у плода починає формуватися досить рано. Згідно 3 даними окремих дослідників, елементи цієї системи розвиваються синхронно й формуються раніше від інших. У плода людини на 11-12-му тижні розвитку в передніх рогах спинного мозку спостерігається поділ сірої речовини на ядра. У ядрі, в якому згодом буде розташований центр, що регулює роботу діафрагми, вирізняються клітини, які за ступенем розвитку значно переважають інші. Легенева та серцево-судинна системи вперше визначаються у 24-денного плода. Встановлена наявність сфінктерного механізму, який періодично відкривається, забезпечуючи витікання та ковтання рідини плодом. Значення амніотичної рідини ще не повністю встановлено, однак вважається, що вона забезпечує формування майбутніх дихальних шляхів $[1,2,3]$.

Антенатальне утворення фосфоліпідів у плода людини і тварин починається 3 18-24-го тижня вагітності. До цього часу відбувається диференціація клітин альвеолярного епітелію, і альвеоцити II типу починають продукувати фосфоліпіди. Їх біосинтез у плода здійснюється двома шляхами: з 20-22-го до 34-36-го тижня розвитку плода із фосфатидилетаноламіну під впливом каталізуючої дії метилтрансферази утворюється пальмітатмірістиллецитин. Активність метилтрансферази знижується за гіпоксії, ацидозу та гіпотермії. Тому при внутрішньоутробній гіпоксії плода порушується утворення сурфактанту ще до народження, що сприяє розвитку асфіксії. Другий шлях утворення сурфактанту починається 3 35-го тижня гестаційного розвитку плода. 3 цього часу холін через низку перетворень за участю ферменту фосфохолінтрансферази (більш стійкого до нестачі оксигену), трансформується в дипальмітолецитин, який $є$ основною складовою зрілого сурфактанту.

Отже, аналіз літературних даних свідчить, що дослідження сурфактанту при наявності змін у перебізі фізіолого-біохімічних процесів в організмі тварин i, передусім, в активності функціональної системи, що підтримує оптимальні значення дихальних показників, не має системного характеру й вимагає поглибленого дослідження.

Метою даної роботи було розробити й запропонувати систему тестів для визначення функціонального стану організму новонароджених телят.
Матеріали та методи дослідження. Для діагностики «зрілості» сурфактантної системи легень та оцінки функціонального стану організму новонароджених телят досліджували:

- функціональну характеристику м'язової системи новонароджених телят за тривалістю часу від народження до першого руху (вставання) та часом появи активного пошуку джерела корму (ссання);

- кількість дихальних рухів - за рухами реберної стінки за 1 хвилину та їх характеристикою;

- кількість серцевих скорочень - на основі залежності між кількістю дихальних рухів та серцевих скорочень. Для цього нами запропоновано двічі, впродовж двох хвилин, визначати кількість дихальних рухів із наступним їх множенням на 4 і 5 і поділом на 2. Наприклад:

$(30 \times 4)+(32 \times 5): 2=140$ серцевих скорочень;

- оптичну щільність амніотичної рідини - за методом Ю. Д. Баліка, Л. А. Урошлева, М. В. Шингерей (1987);

- тривалість зсідання крові з амніотичною рідиною - методом, що грунтується на тромболітичній активністі фосфоліпідів амніотичної рідини. При додаванні амніотичної рідини до крові корів наявні в ній фосфоліпіди прискорюють процес згортання крові;

- вміст креатиніну в навколоплідній рідині - за методом Яффе, з використанням пікринової кислоти;

- час закриття судин пупкового канатика - за часом припинення виділення крові з судин пуповини;

- час виділення меконію - візуально.

За показниками вищезазначених тестів діагностували «зрілість» сурфактантної системи легень i функціональний стан телят, який оцінювали в балах. Залежно від кількості отриманих балів телят відносили до однієї з груп:

- телята, які за вищезазначеними тестами отримали 20 балів і вище, відносили до групи клінічно здорових новонароджених тварин (контрольна група телят).

Телят, які за вищезазначеними тестами отримали 0 балів, відносили до тих, які народилися у стані глибокої гіпоксії (перша дослідна група);

- від 10 до 14 балів - телята, які народилися 3 неадекватними, спонтанними дихальними рухами (стан середнього рівня гіпоксії, друга дослідна група);

- від 15 до 19 балів - телята, які після народження мали спонтанні, адекватні дихальні рухи (стан легкої гіпоксії, третя дослідна група).

Результати досліджень. Наявність постійного контакту легенів із навколоплідною рідиною дає підстави апріорно вважати, що за якісним скла- 
дом амніотичної рідини можна судити про стан плода, «зрілість ССЛ» і процеси, що в ній відбуваються. Тому цілком закономірною є думка, що динамічний контроль складу навколоплідної рідини є одним із найбільш вірогідних способів діагностики стану плода, а в майбутньому i opганізму новонароджених телят.

У процесі моніторингу родової діяльності корів нами встановлено, що телята народжуються 3 різним ступенем ураження гіпоксією. 3 урахуванням вищезазначеного, нами розроблена й запропонована система тестів для діагностики «зрілості» сурфактантної системи легень і оцінки функціонального стану організму новонароджених телят.

Спостереження за новонародженими телятами, які після народження мали порушення процесу дихання, дозволило нам розробити й запропонувати систему тестів для діагностики «зрілості» сурфактантної системи легень і на їх основі проводити бальну оцінку функціонального стану організму. Для цього нами використано параметри найбільш адаптованих до моменту народження систем (дихальна, серцево-судинна, м'язова, видільна).

Встановлено, що кількість дихальних рухів за 1 хвилину у клінічно здорових телят становила, в середньому, $35,0 \pm 3,0$. У телят, які народилися у стані легкої гіпоксії (після народження мали спонтанні адекватні дихальні рухи), їх кількість, у середньому, складала $30,0 \pm 4,0$ за 1 хвилину, а у телят, які народилися у стані середнього рівня гіпоксії (II група), кількість дихальних рухів

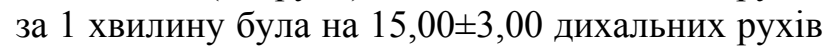
$(20,00 \pm 4,00)$ меншою, ніж у клінічно здорових телят ( $\mathrm{y} 1,75$ разу нижча, $\mathrm{p}<0,01)$. Частота серцевих скорочень у клінічно здорових новонароджених телят становила $152 \pm 6,0$ за 1 хв. і була в 1,52 та 1,32 рази більшою, ніж у телят, які народилися у стані легкої та середньої гіпоксії $(\mathrm{p}<0,01)$. М'язова активність новонароджених клінічно здорових телят, отриманих від корівпервісток, проявилася на $25 \%$ раніше, ніж у телят, які народились у стані гіпоксії. Адаптаційні рефлекси клінічно здорових телят, отриманих від корів другої й третьої груп, проявилися раніше, ніж у телят, які народилися у стані гіпоксії.

Нами також встановлено, що час від народження до перших активних рухів (рис. 1) у клінічно здорових телят становив $35 \pm 3,0$ хвилини. У телят дослідних груп м'язовий тонус організму виявився слабким (рис. 2). Час від народження до перших рухів у телят II та III груп, у середньому, становив від $37,00 \pm 3,00$ до 42,00 $\pm 5,00$ хвилин.

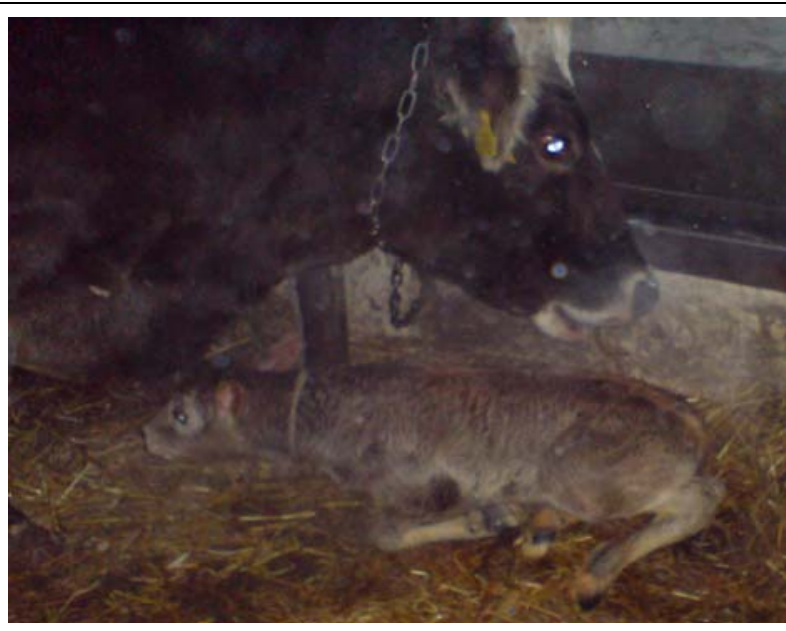

Рис. 1. Перші рухи клінічно здорового теляти

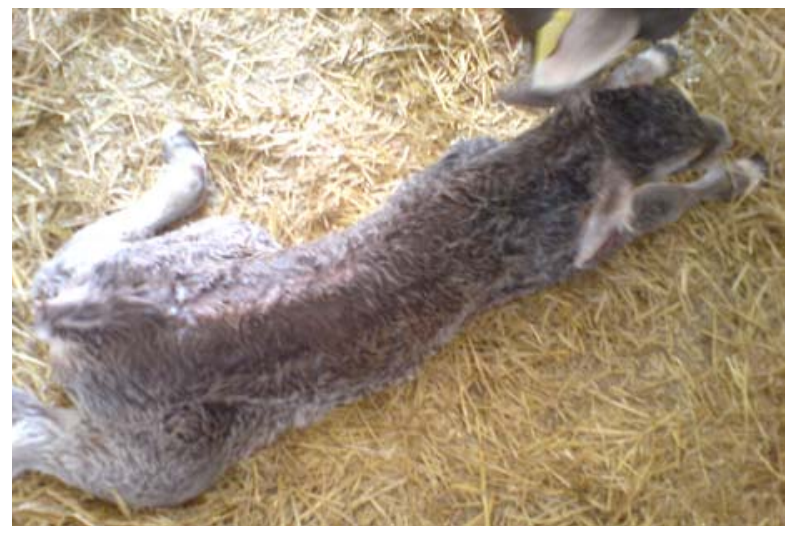

Рис. 2. Стан м'язової системи у теляти в стані гіпоксї̈

Рефлекс активного пошуку джерела корму та ссання у клінічно здорових телят починався в середньому через $55,00 \pm 6,00$ хв. після народження (рис. 3). У телят II і III груп даний рефлекс проявлявся відповідно у 1,05-1,15 рази пізніше, ніж у клінічно здорових телят (рис. 4).

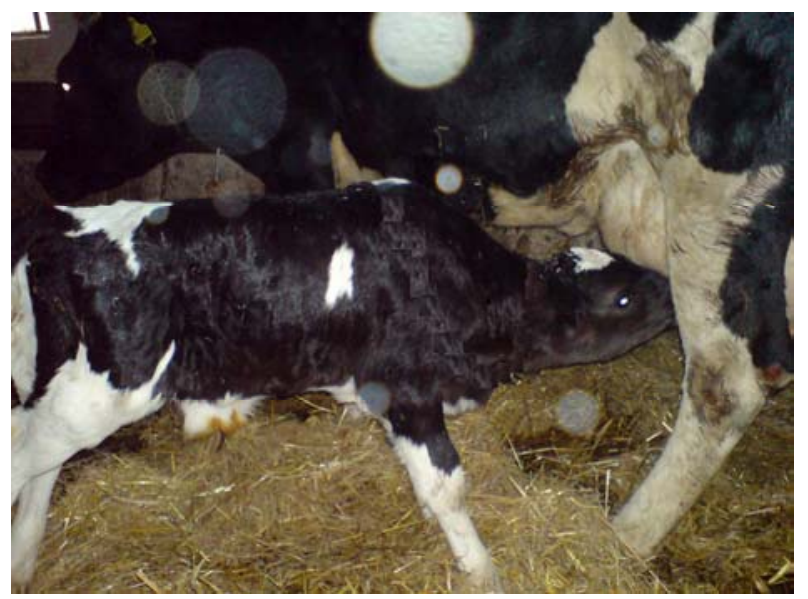

Рис. 3. Отримання першої порції молозива телям контрольної групи 


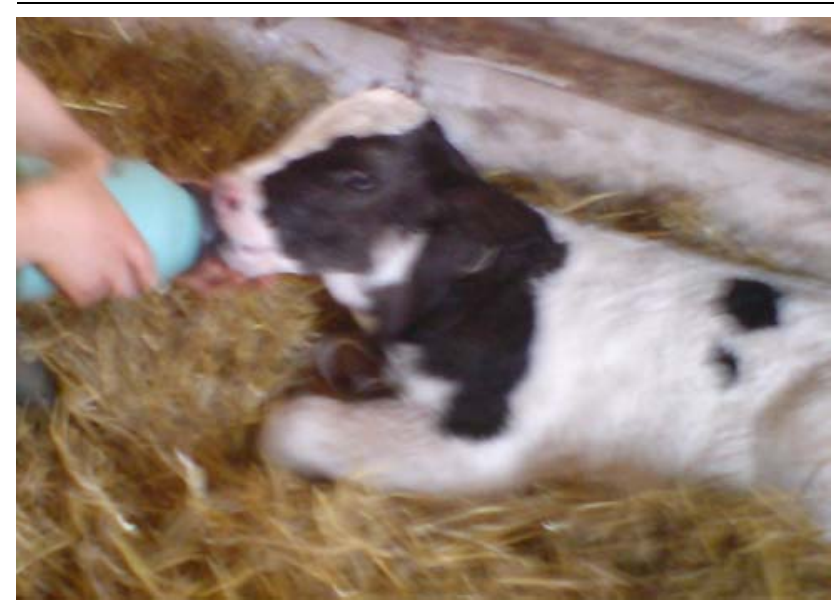

Рис. 4. Випоювання периої порції молозива теляті у стані гіпоксії

Нами також враховано час виділення меконію. Новонароджені клінічно здорові телята, як правило, виділяли сформований первородний кал під час першого прийому молозива (рис. 5). У телят, які народилися у стані гіпоксії, виділення меконію відбувалося впродовж першої-другої доби життя, або телята народжувалися з меконієм у навколоплідній рідині (рис. 6).

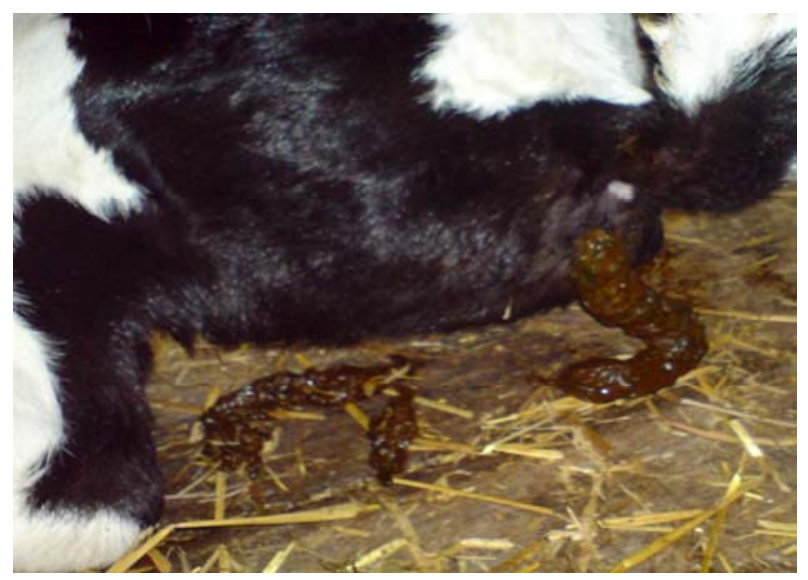

Рис. 5. Виділення меконію здоровим телям

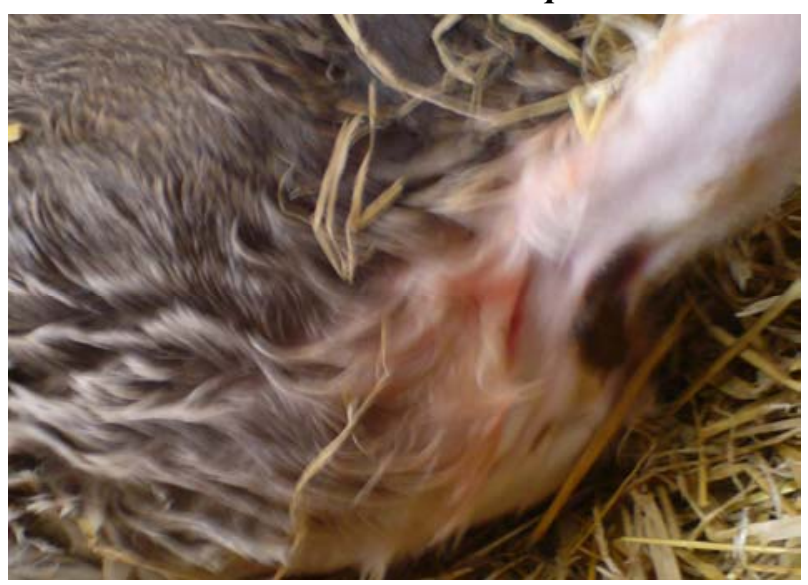

Рис. 6. Виділення меконію від теляти, яке народилося у стані гіпоксії
Час закриття судин пупкового канатика у клінічно здорових телят становив у середньому $45,00 \pm 3,0$ сек. (рис. 7), а у телят другої й третьої груп (рис. 8) цей процес тривав у 2,00-3,30 рази довше $(\mathrm{p}<0,01)$.

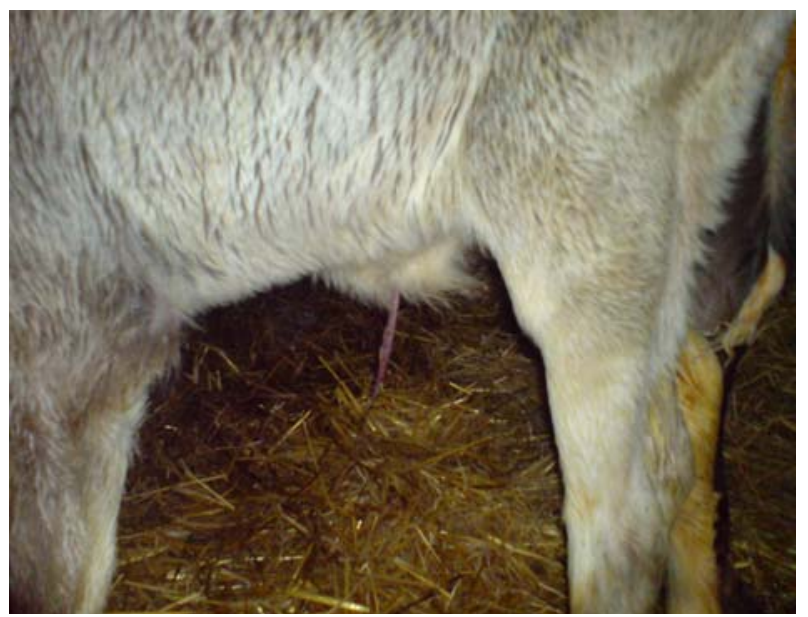

Рис. 7. Зовнішній вигляд пупкового канатика клінічно здорового теляти

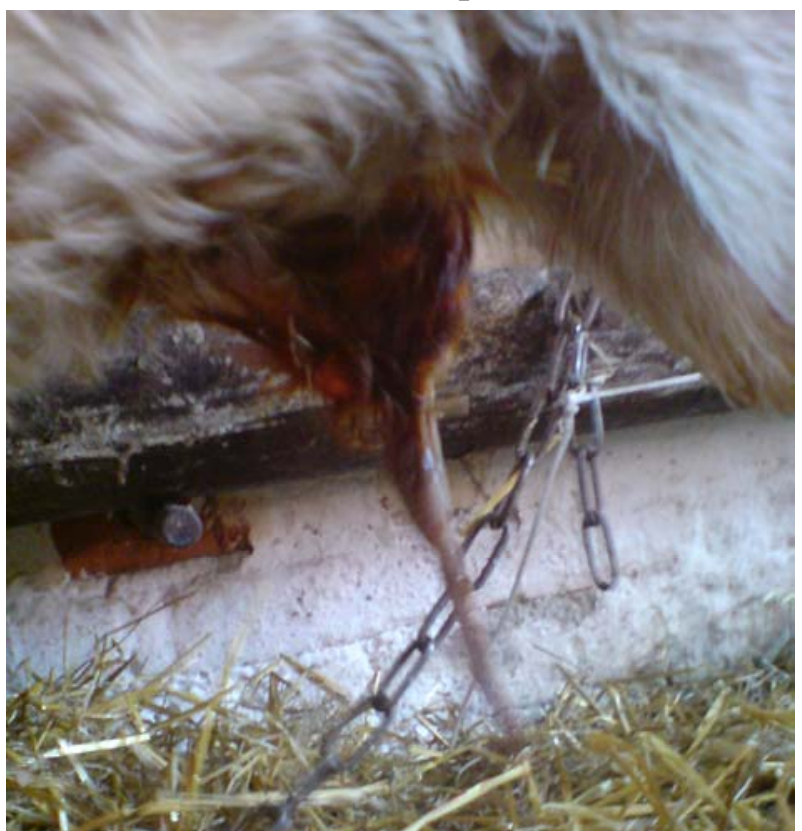

Рис. 8. Зовнішній вигляд пупкового канатика теляти, яке народилося у стані гіпоксії

Про «зрілість» сурфактантної системи легень, a отже, й функціонального стану організму новонароджених телят свідчать також і наступні показники.

Тривалість зсідання крові корів, які народили клінічно здорових телят, 3 амніотичною рідиною становила в середньому $105,00 \pm 6,00$ секунд. Тривалість даного процесу з амніотичною рідиною телят, які народилися у стані гіпоксії (II і III група), була вірогідно довшою (у 1,95-1,43 рази, $\mathrm{p}<0,01)$. 
Оптична щільність амніотичної рідини телят, які народилися клінічно здоровими, виявилася більшою і становила $0,16 \pm 0,01$. У телят (II і Ш групи), які народилися у стані гіпоксії; вона зменшувалася вірогідно у 2,11-1,78 рази $(\mathrm{p}<0,01)$.

Вміст креатиніну в амніотичній рідині телят, які народилися клінічно здоровими, досягав $138,00 \pm 3,65$ мкмоль/л. У телят другої та третьої груп вміст даного метаболіту білкового обміну в амніотичній рідині був меншим у 1,67-1,39 рази $(\mathrm{p}<0,01)$.

Запропоновані нами тести щодо оцінки «зрілості» сурфактантної системи легень та функціонального стану організму новонароджених телят дозволили врахувати фізіологічний прояв основних безумовних рефлексів, які після народження тварин забезпечують їх адаптацію до нових умов існування.

За показниками запропонованих тестів ми відносили новонароджених телят до групи клінічно здорових (контроль) або до групи телят, які народилися у стані гіпоксії.

Враховуючи вищенаведене, нами запропоновано розподіляти новонароджених телят, які народилися у стані гіпоксії, на такі групи:

- телята, які народилися без ознак зовнішнього дихання або з наявним меконієм у навколоплідній рідині й які за запропонованою нами системою діагностичних тестів отримують 0 балів до першої групи дослідних телят (стан глибокої гіпоксіі);

- телята, які народилися зі спонтанними неадекватними дихальними рухами і які за системою тестів отримують 10-14 балів, - до другої групи дослідних тварин (стан середньої гіпоксії);

- телята, які народилися зі спонтанними адекватними дихальними рухами і які за системою

\section{БІБЛІОГРАФІЯ}

1. Дудаева Т. Ю. Влияние острой гипоксии раннего органогенеза на развитие потомства белых крыс / Т. Ю. Дудаева, А. В. Граф, А. С. Аксакова, Л. К. Трофимовна, Н. А. Соколова // XX съезда Физиологического общества им. И. П. Павлова : Тезисы докладов. - М. : Издательский дом «Русский врач», 2007. - 218 с.

2. Общая пульмонология: руководство для врачей / Н. И. Александрова, А. Г. Бобков, Н. А. Богданов [и др.]; под ред. Р. Н. Палеева. - М. : Медицина, тестів отримують 15-19 балів, - до третьої групи дослідних тварин (стан легкої гіпоксії).

Телят, які народилися клінічно здоровими і за системою тестів отримали понад 20 балів, відносили до контрольної групи.

Використання показників навколоплідної рідини для діагностики «зрілості» сурфактантної системи легень плода й новонароджених телят, а отже, й функціонального стану організму після народження дало змогу чітко проводити вказану диференціацію і в умовах виробництва організовувати профілактичні або лікувальні адекватні заходи відповідно до функціонального стану новонароджених телят.

\section{Висновки:}

1. Вміст креатиніну в навколоплідній рідині клінічно здорових новонароджених телят виявися в 1,67-1,39 рази ( $<<0,01)$, а оптична щільність амніотичної рідини у $2,11-1,78$ рази $(\mathrm{p}<0,01)$ більшою, ніж у телят, які народилися у стані гіпоксії.

2. Згортання крові корів-матерів клінічно здорових новонароджених телят 3 амніотичною рідиною відбувалося у $1,95-1,74$ рази $(\mathrm{p}<0,001)$ швидше, ніж у корів, які народили телят у стані гіпоксії.

3. Запропоновані нами тести оцінки функціональної активності новонароджених телят дають можливість своєчасно виявляти 3-поміж них телят у стані гіпоксії й проводити відповідні профілактичні та лікувальні заходи.

4. Запропоновано 20-бальну систему діагностичних тестів для оцінки «зрілості» сурфактантної системи легень, а, відповідно, й функціонального стану організму новонароджених телят та ступеня впливу гіпоксії на плід.

1989. -640 c.

3. Радзинский В. Е. Экстраэмбриональные и околоплодные стуктуры при нормальной и осложненной беременности / В. Е. Радзинский, А. П. Милованов. - М. : МИА, 2004. - 391 с.

4. Уэсm Джс. Физиология дыхания / Дж. Уэст // Основы : пер. с англ. - М. : Мир, 1998. - 200 с.

5. Chander $A$. Regulation of lung surfactant secretion / A. Chander, A. B. Fisher // Am. J. Phisiol. 1990. - V. 258. - P. 241-253. 